\title{
O movimento pelos direitos da criança e do adolescente e o controle social sobre a política socioeducativa: Repertórios de interação socioestatal
}

Maria do Carmo Alves de Albuquerque'

\section{Resumo}

Este artigo trata do movimento pelos direitos da criança e adolescente (movimento DCA) em sua ação de incidência - ou controle social - sobre a política socioeducativa. Busca uma nova perspectiva de análise sobre este movimento social que permita refletir sobre seus resultados na conquista das políticas públicas para a efetivação do paradigma de garantia de direitos à criança e ao adolescente. Para tal foi preciso buscar novos referenciais teóricos adequados para pensar esta forma de atuação, examinando os repertórios de interação entre o movimento e o Estado. Entre eles a participação institucional através de instituições participativas como Conselhos e Conferências, a ocupação de cargos no Estado e, especialmente, a articulação entre os atores societais do movimento DCA e os atores estatais incumbidos legalmente de realizar o controle público sobre a política. $\mathrm{O}$ artigo se baseia em pesquisa docente com base em análise documental e observação de campo de atores e espaços de ação do movimento social DCA. Nota-se a importância de articular uma perspectiva teórica movimentalista, focando os repertórios da ação coletiva, com uma perspectiva de análise de políticas públicas. Analisar padrões de interdependência entre atores sociais e Estado é essencial para fugir da avaliação simplista de que a interação entre Estado e movimento leva à burocratização e cooptação e para entender o significado e o lugar do movimento no controle social da política pública.

Palavras-chave: Movimento social. Controle social. Repertórios de interação socioestatal. Coalizões de defesa. Adolescente em conflito com a lei.

Doutora em Integração da América Latina pela Universidade de São Paulo (USP). Mestre em Ciência Política pela Universidade Estadual de Campinas (Unicamp). Professora da Universidade Anhanguera de São Paulo (Unian) e pesquisadora do Centro Brasileiro de Análise e Planejamento (Cebrap).

E-mail:mcarmoa@gmail.com. 


\section{Introdução}

Diversos autores têm apontado a insuficiência da literatura clássica sobre movimentos sociais para um estudo adequado da açáo dos movimentos no Brasil, principalmente após a estabilizaçáo do regime democrático e a ampliação da democracia que se seguem à Constituição de $1988^{2}$.

O "modelo clássico" foi criticado por autores como McAdam, Tarrow e Tilly (2009, apud ABERS; BÜLOW, 2011) que apontaram a necessidade de enfatizar os processos políticos nos quais se desenvolve a ação coletiva e os seus repertórios de ação conflituosa (TILLY, 2010; TARROW, 2009).

Essa perspectiva vem sendo recentemente explorada por autores brasileiros como Abers, Serafim e Tatagiba (2014), Abers e Bülow (2011), Carlos (2011), Sherer-Warren e Lüchmann (2011), Dowbor (2012), Silva e Oliveira (2011), entre outros que, no entanto, problematizam a caracterização dessa ação conflituosa, explicitando e acentuando a importância do estudo sobre a interação socioestatal dos movimentos sociais. Estes autores buscam uma nova maneira de ver os movimentos que permita pensar sua participação na construção democrática no Brasil e sua incidência em políticas públicas, a fim de ampliar a perspectiva de análise do movimento social para além dos estudos que mais frequentemente se focaram nas suas dinâmicas de ação no interior da sociedade, em conflito e oposição ao Estado, pensado como exterior a ele. E acrescentar um olhar sobre o seu repertório de açóes que interagem com atores do Estado.

O envolvimento dos movimentos sociais é acentuado mediante esforços por democratizar o Estado, que também se notam em toda a América Latina (ABERS; BÜLOW, 2011). No Brasil, os movimentos desempenham importante papel na construção democrática (ALBUQUERQUE, 1997), pois há forte interação com agentes públicos estatais (ABERS; SERAFIM; TATAGIBA, 2014) e contínua incidência nas políticas sociais em todas as suas fases: a formação da agenda pública, a proposição de normativas e instrumentos de política pública, a execução, o monitoramento e a avaliação das políticas (ALBUQUERQUE, 2007). A participação e a incidência da sociedade,

2 Albuquerque (1997) examina essa transição e o papel - uma nova fase - dos movimentos sociais na construção da democracia no Brasil. 
especialmente dos movimentos sociais, nas políticas públicas é normatizada, na legislação que segue a Constituição de 1988, como "controle social" sobre as políticas públicas e se exerce por meio de novas instituiçóes participativas (IPs) como Conselhos e Conferências de políticas públicas - conforme a Constituição federal, em seus artigos 29, 194, 198, 204 e 227 (BRASIL, 1988); as Leis Orgânicas da Saúde, Leis no 8.080/90 (BRASIL, 1990b) e $n^{\circ}$ 8.142/90 (BRASIL, 1990c); Lei Orgânica da Assistência Social, Lei no 8.742/93 (BRASIL, 1993); o Estatuto da Criança e do Adolescente (ECA), Lei no 8.069 (BRASIL, 1990a), entre outras.

Este artigo insere o "movimento pelos Direitos da Criança e do Adolescente (movimento DCA)" 3 neste debate, buscando compreender sua contribuição para a "política socioeducativa"4. Para tal analisa seus diferentes repertórios de ação, explicitando a interaçáo entre movimento e Estado, com as características próprias deste movimento social.

O movimento social é entendido, conforme detalharemos adiante, como um conjunto heterogêneo integrado por diferentes organizaçóes, grupos e indivíduos ativistas que, no entanto, possuem identidades coletivas compartilhadas. No caso do movimento DCA, esta identidade se constitui em torno das lutas pela incorporação do "paradigma garantista" na legislação e na política pública de Direitos da Criança e do Adolescente.

O ideário ou paradigma "garantista", conhecido como a "Doutrina da proteção integral" se consolida desde o fim dos anos 1980 em oposição ao "paradigma menorista", que caracterizou, até entáo, as políticas para crianças e adolescentes entendidos como "menores" em "situaçáo irregular": órfãos, pobres, abandonados e infratores.

Sem negar a heterogeneidade do movimento, identificamos uma ação coordenada em torno de repertórios de ação que confluíram para a operacionalização desse paradigma, com seus inúmeros tropeços, nas legislaçóes e

3 Para mais informações: <http://www.mdca.org.br/index.php>.

4 Dentro da política de direitos da criança e do adolescente, definida principalmente pelos artigos 227 e 228 da Constituição Federal e pelo Estatuto da Criança e do Adolescente (ECA), a política socioeducativa é a que trata do atendimento e dos direitos do adolescente em conflito com a lei e é definida pela Lei $n^{\circ}$ 12.594, de 18 de janeiro de 2012 (Lei do Sinase - Sistema Nacional de Atendimento Socioeducativo). 0 artigo parte das dimensões nacional e estadual desta política, mas se detém no seu âmbito municipal. 
políticas públicas que decorrem do ECA e do Sistema nacional de atendimento socioeducativo (Sinase).

Buscamos estudar a participação social na sua relação com a política pública na qual incide (DOWBOR, 2012), analisando o movimento social como uma das partes interessadas (stakeholders) nessa política pública. Entre estas partes, ou atores, que constituem a "comunidade" envolvida nesta política (SABATIER; WEIBLE, 2007), este artigo analisa o lugar (ou papel) ocupado pelo movimento social.

Os resultados alcançados permitem enxergar o movimento social como um dos atores relevantes na formação e na implementação da política pública socioeducativa. Sua participação ocorre na inter-relação com atores estatais que integram o conjunto de atores nela implicados: Poder Executivo, Poder Legislativo, Poder Judiciário, e Ministério Público. Notam-se relaçóes de interdependência entre eles, o que corrobora a perspectiva teórica da mútua constituição entre sociedade civil e Estado (DAGNINO, 2011, p. 124).

Restam muitos desafios de análise, explorando tensóes e diferenças entre os atores - quer estatais, quer societais -, entre os quais muitos posicionados contra o "paradigma garantista" ou mesmo divididos por outras clivagens. O objetivo deste estudo se restringiu, porém, a explicitar repertórios de ação caracterizados pela interaçáo socioestatal.

$\mathrm{O}$ artigo parte da caracterização dos "repertórios de interação" propostos por Abers, Serafim e Tatagiba (2014) e analisa as características desses repertórios no movimento DCA. Chega-se, assim, a uma caracterização ampliada de "repertórios de interação" socioestatal e à análise de uma tipologia destes, entre os quais o confronto associado à negociação, o trânsito de atores entre Estado e sociedade, e a articulação entre controle social e controle estatal.

\section{Repertórios de interação socioestatal e coalizões de defesa}

A literatura sobre os movimentos sociais tem-se voltado principalmente para sua face societal, enfatizando seu caráter de construção de identidades sociais coletivas nas lutas reivindicativas de confronto e oposição ao Estado. Os movimentos sociais foram saudados por sua espontaneidade contrastante 
com a organização formal de outros atores (KOWARICK, 1987), por sua lógica do mundo da vida, contrastante com a lógica sistêmica, postuladas por Habermas (COSTA, 1994), especialmente no período da reconstrução das democracias na América Latina.

Essa perspectiva se acentuou, no Brasil, quando da emergência vigorosa de movimentos sociais nas lutas contra a ditadura, pela democratização e por direitos sociais. Os novos movimentos no Brasil, como aponta Paoli (1995, p. 27), “[...] não se referenciavam diretamente às estruturas institucionais de poder e representação política - partidos, governo, Estado - nem aos atores "clássicos"”. Sua originalidade, sua novidade estava na "aspiração de um poder civil e cidadão", estava em "[...] escapar de uma institucionalidade estatal”, a qual era "[...] tutelar, autoritária e burocrática" (PAOLI, 1995, p. 32). Nesse período se acentuou o caráter de confronto entre Estado e movimento e surgiu uma forte reivindicação de autonomia e independência dos movimentos, que se opôs ao passado populista e autoritário, marcado pela instrumentalização dos sindicatos e movimentos sociais ${ }^{5}$ no Brasil.

Essa reivindicação de autonomia convive, no entanto, com o caráter de reivindicação de direitos e de políticas públicas que assumem muitos movimentos sociais no Brasil. Esse caráter provoca a intensificação das relações entre movimento e Estado e o desenvolvimento de um amplo repertório de açóes de interação entre eles - que inclui os protestos, mas vai além deles. Gera-se, nesse processo, uma multiplicidade de novos espaços e instituiçóes participativas (IPs) que vêm a se constituir em interfaces ocasionais ou permanentes de diálogo e negociaçáo entre atores estatais e societais tais como Fóruns, Conselhos e conferências de políticas públicas.

A face institucional dos movimentos, com base na literatura focada na açáo societal e de confronto com o Estado, foi frequentemente vista como um defeito dos movimentos, um perigo de serem "colonizados" pelos atores marcados pela "lógica sistêmica" habermasiana - perigo de cooptação ou instrumentalização pelo Estado e partidos políticos. Essa perspectiva dicotômica,

5 Com os "novos movimentos" surgidos nas lutas contra a ditadura, surgiu o "novo sindicalismo" - em oposição ao sindicalismo burocratizado e "pelego" das décadas anteriores - e os movimentos populares urbanos - que buscaram marcar sua autonomia diferenciando-se das "Sociedades Amigos de Bairros" (SABs), estas muitas vezes criadas e manipuladas por políticos populistas como Jânio Quadros em São Paulo. 
que analisou Estado e sociedade como entidades separadas e regidas por lógicas distintas, dificultou a análise da açáo dos movimentos sociais brasileiros no período pós-ditadura e sua significativa incidência na construção da democracia e de novas políticas sociais.

Uma nova literatura vem buscando, ao contrário, propor "[...] uma perspectiva de análise que possibilite apreender diferentes padróes de relação entre política institucionalizada e política náo institucionalizada". Ela enfatiza "uma abordagem relacional no estudo dos movimentos sociais" e busca analisar como diferentes padróes de relação geram formatos distintos de "organização e atuaçáo dos movimentos sociais” (SILVA; OLIVEIRA, 2011, p. 88). Ao invés de pensar a interação com a política como um defeito ou ameaça à autenticidade do movimento, passa a ver essa interaçáo como constitutiva de sua ação.

Para isso, é necessário mobilizar uma literatura que desloca sua atenção do ator social para o processo político com o qual ele interage, do objeto da ação coletiva para a sua forma - os repertórios de ação. Tilly (2010) e outros estudiosos da chamada "abordagem do confronto politico" argumentam que os movimentos escolhem entre um conjunto de formas de ação, com as quais têm experiência e que são social e politicamente legitimadas e criativamente ressignificadas e reconstruídas (ABERS; SERAFIM; TATAGIBA, 2014; TARROW, 2009, p. 51). Este conjunto constitui o repertório de ação do movimento.

Abers, Serafim e Tatagiba (2014) argumentam que, embora útil para entender a ação dos movimentos, esta abordagem tem visto a relação entre Estado e movimento apenas sob a chave do conflito e os repertórios de protesto têm assumido centralidade. Para o caso brasileiro, com a forte relação dos movimentos com a construção de novas políticas públicas, as autoras constroem o conceito de "repertório de interação" socioestatal. Entre as diferentes formas de interação entre movimento e Estado, destacam, além dos protestos, quatro novas categorias - a ocupaçáo de cargos no Estado, a política de proximidade, o lobby parlamentar e a participação institucionalizada - participação nos espaços de controle social, especialmente os Conselhos e Conferências de políticas públicas.

Neste sentido, Silva e Oliveira (2011) referem-se às intersecçóes entre Estado e movimento e ao trânsito de ativistas que atuam ora no movimento ora no Estado. Dessa forma se nota uma permeabilidade das fronteiras entre o movimento social e o Estado (ABERS; BÜLOW, 2011). 
O debate se desloca, assim, de um foco centrado na análise do ator (o movimento social, os atores da sociedade civil ou a ação coletiva) para as relaçóes ou interaçóes do movimento com outros atores, seja no campo da sociedade civil seja fora dele (Estado, partidos etc.). Evidencia-se a necessidade de conhecer o conjunto dos atores que incidem na política pública, tanto atores da sociedade civil quanto atores estatais que, no caso das políticas de Direitos da Criança e do Adolescente, articulam-se, "encaixam-se", constituem alianças ou coalizóes em momentos essenciais da operacionalização de um novo paradigma de direitos - o chamado "paradigma garantista".

Para examinar essas alianças, buscamos as teorias de políticas públicas que discutem o papel do Estado e dos atores econômicos e societais na sua origem e formulação. Na perspectiva neoinstitucionalista, Skocpol (1985) destaca a importância dos "pontos de encaixe" entre o Estado e os grupos que incidem politicamente na vida pública:

Os significados da vida pública e as formas através das quais os grupos coletivos tornam-se conscientes dos objetivos políticos e trabalham para atingi-los surgem, não da sociedade por si só, mas nos pontos de encaixe entre Estado e sociedade. (SKOCPOL, 1985, p. 26) ${ }^{6}$.

Skocpol valoriza os pontos de encaixe, os momentos de encontro entre Estado e sociedade que contribuem para a construçáo dos objetivos políticos dos atores sociais. Também recorremos a Kingdon (1995), e a Sabatier e Weible (2007) para analisar o papel do conjunto de atores que incidem em uma política pública - as "comunidades de políticas" - e, dentro delas, as "coalizóes de defesa" - que articulam atores distintos em torno de conjuntos de crenças e propostas para uma dada política. Entre os tipos de crenças que dão origem a coalizóes, estão as crenças mais centrais e profundas ligadas a princípios gerais e, em um segundo nível, as crenças ligadas a uma política setorial, "[...] que projetam uma imagem de como o subsistema de política deveria ser, fornecem a visão que orienta o comportamento estratégico da coalizão, e ajudam a unir aliados e dividir adversários" (SABATIER; WEIBLE, 2007, p. 195). No entanto, para a formação das coalizóes, além de compartilhar crenças é preciso que os atores comecem a se coordenar - trabalhar juntos para atingirem

6 As traduções são da autora do artigo. 
objetivos semelhantes. O conceito de coalizão de defesa também contribui para superar uma dicotomia simples entre sociedade e Estado.

Compreender a complexidade da interaçáo entre movimento e Estado, evitando dicotomias e julgamentos normativos, é essencial para o estudo dos movimentos sociais no Brasil, especialmente aqueles que focam sua ação na conquista de direitos e de políticas públicas garantidoras de direitos.

É o que vêm fazendo Dowbor (2012), em relação ao movimento sanitarista; Tatagiba (2011), em relação aos movimentos de moradia; Silva e Oliveira (2011), em relação ao movimento de Economia Solidária. Este artigo busca realizar um estudo análogo em relaçáo a outro movimento que luta por políticas de direitos - o movimento social pelos Direitos da Criança e do Adolescente (movimento DCA). Examina os repertórios de interação entre este movimento e o Estado, especialmente aqueles que envolvem articulaçóes ou coalizóes de atores societais e estatais em torno da crença compartilhada no "paradigma garantista", e que se traduz em açóes articuladas pela construção de um conjunto de políticas públicas sintonizada com esse paradigma.

\section{0 movimento DCA - breve apresentação}

Analisamos a incidência do movimento pelos Direitos da Criança e do Adolescente (que denominamos movimento DCA) na política socioeducativa, um subsetor da política de Direitos da Criança e do Adolescente (política DCA).

O movimento DCA emerge com essa denominação ou outras semelhantes nas falas de seus próprios ativistas, principalmente nos anos de luta pelo reconhecimento do "paradigma garantista" na Constituição Federal no ECA (BRASIL, 1988, 1990a), conforme relatam estudos acadêmicos de alguns deles ${ }^{7}$. Hoje quase não mais se fala em movimento, mas em Fóruns e redes.

Neste artigo, consideramos o conjunto dessas redes e desses fóruns como "o movimento DCA" tomando como base a definição de Diani:

Movimentos sociais são definidos como redes de interação informal entre uma pluralidade de indivíduos, grupos e/ou organizações, engajadas em conflitos políticos ou culturais, com base em identidades coletivas compartilhadas. (1992, p. I).

7 Erivã Velasco, Secretária Nacional FNDCA fala em "movimento dos direitos humanos de crianças e adolescentes" (FNDCA, 2010), Pereira (1996) fala em "Movimento de defesa dos direitos da criança e do adolescente", Pini (2006) cita o "movimento da infância e da adolescência". 
Essa definição permite ver o movimento DCA como uma pluralidade de organizaçóes (ONGs, Fóruns etc.), grupos e indivíduos que se articulam e se engajam na construção de um paradigma de Direitos da Criança e do Adolescente, denominado "paradigma garantista", e das políticas públicas que o concretizam desde o período da Constituinte e de criação do Estatuto da Criança e do Adolescente (ECA).

Esse movimento é herdeiro de um movimento internacional de luta pelos direitos da infância com quem ele compartilha um conjunto de crenças e propostas políticas que se definem como o "paradigma garantista" - construído na oposição ao paradigma "menorista", que discriminava o "menor" - carente, abandonado ou infrator - com políticas assistencialistas e repressivas a ele destinadas. Contra esta diferenciaçáo discriminadora, o "paradigma garantista" define a criança e o adolescente como sujeitos de direitos, os quais se traduzem em políticas públicas de garantia de direitos. A construção desta identidade remonta ao fim da primeira guerra mundial quando organizaçóes sociais reivindicaram e negociaram junto às nascentes Naçóes Unidas o que veio a ser, em 1924, a Declaração de Genebra dos Direitos da Criança. Desde entáo, diversos atores societais interagiram na perspectiva de construir um paradigma de direitos da criança e do adolescente, que se consolida como o novo "paradigma garantista" na Convençáo da ONU sobre os Direitos da Criança e do Adolescente, em 1989.

Para descrever o movimento DCA, neste artigo destacamos três importantes momentos ou ciclos de mobilização desse movimento no Brasil. Com isto, não faremos uma descrição exaustiva do movimento DCA, que vem diversificando suas frentes de luta e formas de organização. Inúmeras outras organizaçóes, redes e fóruns (nacionais, estaduais, locais, internacionais) seriam identificados caso nosso foco fossem outros processos de mobilizaçáo, tais como a luta contra o trabalho infantil ou para a eliminaçáo da exploração sexual de crianças e adolescentes. Em torno de outros ciclos de mobilizaçáo, encontraríamos outros atores societais integrando o movimento, e outros atores estatais interagindo com ele ${ }^{8}$.

8 Como exemplos, citamos duas redes nacionais, com organização nos estados e municípios: a Rede ECPAT Brasil é uma coalizão de organizações da sociedade civil que trabalha para a eliminação da exploração sexual de crianças e adolescentes, compreendendo as suas quatro dimensões: prostituição, pornografia, tráfico e turismo para fins de exploração sexual. Existe desde 1997, a partir do "I Congresso Internacional de Combate 
Em cada um dos ciclos aqui analisados, voltados a pensar a incidência do movimento na política socioeducativa em São Paulo. Organizações, grupos e indivíduos distintos se destacam como integrantes e protagonistas principais desse movimento. Eles aparecem na Tabela 1, na coluna "Atores societais".

Embora não façamos uma análise precisa sobre o início e o fim de cada ciclo, eles têm momentos de pico sucessivos no tempo. A análise do primeiro ciclo será nacional; do segundo, será focada no Estado de São Paulo; e do terceiro, no Município de São Paulo, de acordo com as competências de cada um destes âmbitos na política socioeducativa. Os três ciclos de mobilizaçáo correspondem a conquistas importantes nas políticas que garantem direitos às crianças e aos adolescentes nos âmbitos federal, estadual e municipal.

O primeiro ciclo teve como pico a criaçáo do ECA. Iniciou na década de 1980, quando surgiram e se articularam a Pastoral do Menor da Igreja Católica, o Movimento Nacional dos Meninos e Meninas de Rua (MNMMR), e uma multiplicidade de outras organizaçóes e indivíduos que se engajaram na defesa dos Direitos da Criança e do Adolescente. Surgiram novas organizaçóes voltadas explicitamente a essa defesa - os Centros de Defesa da Criança e do Adolescente (Cedecas) e a Associaçáo Nacional dos Cedecas (ANCED) ${ }^{9}$ que contribuíram decisivamente para a construção da identidade do movimento com a construção da noçáo de "justiça garantista", base do novo paradigma e da nova legislação. Segundo Souza ([s. d.], [s.p.]), entre os atores societais que integraram o movimento, destacaram-se profissionais e organizaçóes profissionais, como sindicatos e conselhos profissionais, a Associação de Juízes da Infância, a Sociedade Brasileira de Pediatria, entre outros ${ }^{10}$.

à Exploração Sexual Comercial de Crianças e Adolescentes", realizado em Estocolmo, em 1996, quando foi criada uma agenda mundial pela eliminação do problema, constituida por organizações da sociedade civil e redes de enfrentamento contra a violência sexual de crianças e adolescentes. Consulte o site: http:/lecpatbrasil.org.br/?page_id=I| 9 >. Na área do trabalho infantil, temos o "Fórum Nacional de Prevenção e Erradicação do Trabalho Infantil", articulação de atores sociais, criado em 1994 com o apoio da Organização Internacional do Trabalho (OIT) e do Fundo das Nações Unidas para a Infância (UNICEF). Saiba mais sobre este fórum. acessando: <http://www.fnpeti.org.br>.

9 Os Cedecas se diferenciam das ONGs voltadas ao atendimento da infância pela missão explícita da defesa de direitos. Criaram a noção de "justiça garantista" que caracterizou o direito do jovem a um processo legal de apuração dos atos infracionais, o que caracteriza o paradigma e a legislação garantistas no Brasil, conforme aponta Nastari (2006). Juntamente com a ANCED, eles se destacam nas lutas garantistas até o momento atual. Consulte o site: <http://www.anced.org.br/>, para obter mais informações.

10 Juizes integrantes da Associação de Curadores da Infância estiveram nos Grupos de Trabalho (GTs) que deram origem à Emenda Constitucional e aos artigos 227 e 228, e à Comissão de Redação do ECA. A associação 
Esse amplo movimento social se somou e articulou aos debates internacionais, avaliou e denunciou a situação nacional, e elaborou propostas para a Constituição Federal, e foram construídas articulaçóes e alianças com atores estatais. A participação do parlamento, órgáo constitucional de controle estatal sobre a administraçáo pública, ocorreu pela fiscalização e denúncia mediante Comissóes Parlamentares de Inquérito, como a "CPI do Menor", em 1975, que se desdobrou em Comissóes Estaduais de Inquérito nos estados (CEIs) (LONGO, 2010, p. 10).

Atores societais, articulados a atores estatais, como juízes, promotores e defensores públicos, além de parlamentares e funcionários públicos das instituições de atenção ao "menor" ", articularam-se e elaboram, em 1987, a emenda popular "Criança Prioridade Nacional”, que originou a Campanha Nacional "Criança Constituinte" que coletou mais de 1,5 milhóes de assinaturas em todo o país, originando os artigos 227 e 228 da Constituição Federal, onde se expressa o "paradigma garantista". Em 1988, foi constituído o Fórum Nacional dos Direitos da Criança e do Adolescente (FNDCA). O movimento se organiza, desde então, por meio de Fóruns que articulam apenas atores societais, nos planos nacional, estadual e municipal.

A aliança entre atores societais e estatais também se fez presente na Comissão para a Redação do ECA, onde, segundo Lorenzi (2007), houve a representação de três grupos expressivos: o "dos movimentos da sociedade civil", o dos juristas (principalmente ligados ao Ministério Público) e o de técnicos de órgãos governamentais (notadamente funcionários da Fundação Nacional do Bem-Estar do Menor - Funabem).

O ECA criou um sistema de instituiçóes participativas (IPs) - os Conselhos e Conferências de Direitos (no nível nacional, estadual e municipal) e os Conselhos Tutelares, nos municípios. Criou, também, as chamadas "Conferências Lúdicas" para a participaçáo de adolescentes e crianças com vistas a inseri-los nas Conferências oficiais. O Conselho Nacional dos Direitos da

se chama hoje Associação Brasileira de Magistrados, Promotores de Justiça e Defensores Públicos da Infância e da Juventude (ABMP). Ver entrevista de Munir Cury no site: <http://www.promenino.org.br/noticias/arquivo/para-munir-cury-transformacao-social-vai-alem-do-estatuto>.

II Entre os atores estatais, destacam-se o Fórum Nacional de Dirigentes de Políticas Estaduais para a Criança e do Adolescente (Fonacriad), atuante até hoje, e a Frente Parlamentar pelos Direitos da Infância e Juventude, criada em 1989, segundo Longo (2010). 
Criança e do Adolescente (Conanda) desempenha papel central na construção do Sistema de Garantia de Direitos para a Criança e o Adolescente (SGD) através de suas Resoluçóes, especialmente a Resoluçáo no 113 de 2006 que desenha e institui este sistema. Esse papel, no entanto, é compartilhado por todas as IPs do Sistema. Nossas observaçóes empíricas mostram, ao lado de muitas fragilidades, a atuação dos Conselhos e Fóruns Estadual e Municipal DCA, bem como dos Conselhos Tutelares nas denúncias de violaçóes de direitos, nas críticas, sugestóes e negociaçóes referentes à política de direitos da infância e juventude. Esse ciclo do movimento e da constituição da política pública é aqui analisado no plano nacional, visto que trata das grandes diretrizes nacionais dessa política.

O segundo ciclo envolve as lutas pela adequação da política socioeducativa ao ECA e pela extinção das Febems ${ }^{12}$, instituições marcadas pela violação de direitos das crianças e dos adolescentes, em momentos de forte confronto. Em São Paulo, os confrontos ocorreram entre 1997 e 2006 e culminaram na extinção da Febem/SP (PALHETA, 2010). Esse ciclo é analisado no âmbito do Estado de São Paulo, visto que a política socioeducativa em meio fechado é de competência estadual. Entre os principais atores, estão: os adolescentes rebelados, a Associação de Mães e Amigos da Criança e do Adolescente em Risco (Amar), os Cedecas e outras ONGs, a OAB (Ordem dos Advogados do Brasil) e outras associaçóes profissionais, bem como organizaçóes internacionais estatais e societais como a Corte Interamericana de Direitos Humanos da OEA e a Anistia Internacional. Conforme a documentação estudada (ver nota 13), vemos que os repertórios de confronto incluíram a realizaçáo de fortes denúncias na mídia, que culminaram com a realização da CPI da Febem (PALHETA, 2010, p. 78-161).

O movimento envolveu-se, ainda, articulado com outros atores societais e estatais, na construção de novas bases nacionais para uma política socioeducativa, que resultaram na legislação recente que regulamenta o Sistema Nacional de Atendimento Socioeducativo (Sinase), recentemente normatizado (BRASIL, 2006, 2012, 2013). O Sinase é

12 As Febems foram criadas pela Politica Nacional de Bem-Estar do Menor (PNBEM) nos anos 1960 e coordenavam a política socioeducativa com medidas de internação e meio aberto. Resistiram muito, até se adequarem ao novo "paradigma garantista" expresso pelo ECA. 
[...] fruto de uma construção coletiva que envolveu nos últimos anos diversas áreas de governo, representantes de entidades e especialistas na área, além de uma série de debates protagonizados por operadores do Sistema de Garantia de Direitos em encontros regionais que cobriram todo o País. (BRASIL, 2006, p. 13).

Nesse processo, as organizaçóes do movimento que se destacam são a ABMP, a ANCED e outras organizaçóes. O papel protagonista é do Conanda e da Secretaria Nacional de Direitos Humanos (SDH).

Em um terceiro ciclo, a análise se foca no processo de construçáo de uma política municipal socioeducativa em meio aberto em Sáo Paulo, que envolve a municipalização das medidas socioeducativas de Liberdade Assistida (LA) e de Prestação de Serviços à Comunidade (PSC), definidas pelo ECA (BRASIL, 1990a) ${ }^{13}$. Seu foco temporal vem até os dias de hoje.

O processo é herdeiro de experiências pioneiras de atendimento aos adolescentes em conflito com a lei, como aquelas desenvolvidas pela Pastoral do Menor desde a década de 1970, com a chamada "Liberdade Assistida Comunitária” (LAC), e apoiadas, técnica e financeiramente, pelo Conanda e pela Secretaria Nacional de Direitos Humanos (SDH) e, em São Paulo, por convênios com a Febem. A partir daí, outras organizaçóes sociais voltadas ao atendimento do adolescente se vincularam à Febem, que organizou a Liberdade Assistida em "Pólos de LA" em todo o Estado de São Paulo (ALBUQUERQUE; BOTELHO; OLIVEIRA, 2013).

$\mathrm{Na}$ capital, surgiu uma articulação das entidades conveniadas com a Febem, que reivindicaram a municipalização do atendimento em meio aberto. Essa "Articulação" lutava pela municipalização e segue até hoje atuando nos Serviços de Medidas Socioeducativas em Meio Aberto (Articulação MSE-MA). A política em meio aberto hoje é municipalizada e faz parte da Política de Assistência Social. Na capital, é gerida pela Secretaria Municipal de Assistência e Desenvolvimento Social (SMADS) ${ }^{14}$ por meio dos Centros de Referencia Especializados de Assistência Social (CREAS).

130 ECA, nos artigos 112 a I19, define a Liberdade Assistida (LA) e a Prestação de Serviços à Comunidade (PSC) como Medidas Socioeducativas em Meio Aberto (Articulação MSE-MA) a que são submetidos os adolescentes infratores. A LAC foi uma precursora das formas de execução da $L A$.

14 A Secretaria de Assistência Social SAS foi redefinida como SMADS. 
A Articulação MSE-MA desempenhou um complexo e polêmico duplo papel de executora da política socioeducativa e de lutar pela sua melhoria. A influência na elaboraçáo da política municipal se traduz atualmente no seu forte envolvimento na construção do Plano Municipal de Atendimento Socioeducativo, detalhamento da política municipal que é legalmente obrigatório. Neste momento se constitui, como em momentos anteriores de elaboração das políticas, uma articulação que envolve um ator estatal (a SMADS) e um ator societal (a Articulação MSE-MA), os quais constituem um GT para a elaboração do Plano Municipal socioeducativo.

Do ponto de vista da organização do movimento, vemos a presença de distintas organizaçóes ou atores societais, especialmente os Fóruns DCA, que se articulam no plano nacional, estadual e municipal. A identidade maior que agrega o movimento é sempre o "paradigma garantista", mas cada ciclo tem componentes específicos desta identidade: no primeiro, a definiçáo das grandes diretrizes que virão a concretizá-lo na política pública de garantia de direitos; nos outros dois, a traduçáo desse paradigma para a situaçáo dos jovens infratores e no atendimento que se dá a eles no âmbito estadual e municipal.

No terceiro ciclo, vemos uma mudança importante na composição do movimento: mais do que o Fórum municipal e regionais DCA, quem desempenhou um protagonismo maior nas lutas pela política socioeducativa foi uma Articulação de organizaçóes conveniadas com o Estado, sempre suspeita de ser cooptada pelo Estado, segundo os ativistas mais tradicionais. Vemos, no entanto, que a Articulaçáo MSE-MA tornou-se um segmento do movimento social DCA, visto que lutava pela implantação do ideário garantista na política socioeducativa, conjunto de crenças que constituíram a identidade do movimento.

Em todos esses momentos ou ciclos, podemos identificar alianças ou 'coalizóes' entre atores societais e estatais - o movimento social (com ONGs, Fóruns, demais organizaçóes e indivíduos ativistas) e os integrantes dos Poderes Executivo, Legislativo e Judiciário e do Ministério Público - atores que integram o que se pode chamar a "comunidade da política" DCA, que se articulam em torno do conjunto de crenças que compartilham e que constitui o "paradigma garantista" e em torno das pautas que buscam a sua operacionalização, como veremos na sequência (KINGDON, 1995; SABATIER; WEIBLE, 2007). Essas coalizóes que se articulam para efetivar o "paradigma 
garantista" se confrontam, porém, com outros atores estatais e societais que não compartilham esse paradigma e que não analisamos neste trabalho.

\section{Procedimentos metodológicos da pesquisa}

Este artigo é fruto de pesquisa docente realizada nos anos 2010 a 2012, que tem continuidade no momento atual. A metodologia utilizada incluiu pesquisa bibliográfica, documental e pesquisa de campo.

A pesquisa de campo se refere ao movimento DCA e à política socioeducativa no Município de São Paulo. Por isso, os dois primeiros ciclos são estudados fundamentalmente a partir da pesquisa bibliográfica e documental ${ }^{15}$, que é voltada a caracterizar o movimento DCA no Brasil e em Sáo Paulo, especialmente seus repertórios de interação socioestatal.

Para o terceiro ciclo, focado na criação e implementação da Política socioeducativa em meio aberto na cidade de São Paulo, foram utilizadas tanto fontes bibliográficas e documentais como pesquisa de campo. Esta envolveu o acompanhamento com observação participante de espaços de controle social da política de Direitos da Criança e do Adolescente em Sáo Paulo, a saber: Fórum Municipal DCA, Fóruns Regionais na Capital, Conselho Municipal DCA, Articulação dos Serviços de Medidas Socioeducativas em Meio Aberto em São Paulo (Articulação MSE-MA), no período 2010-2014.

A bibliografia e os documentos consultados permitiram identificar, em cada um desses ciclos, a presença de atores societais que integraram o movimento DCA, a contínua articulação entre eles e os atores estatais, a presença no movimento social dos vários tipos de repertórios de interação socioestatal e a presença de ativistas que atuam ou atuaram tanto na sociedade civil como no Estado - no Poder Judiciário e no Ministério Público (principalmente Defensoria e Promotoria Públicas), no Poder Legislativo e em órgãos do Executivo, como Ministérios, Secretarias de Governo e instituiçóes socioeducativas, por exemplo, unidades da Febem.

15 Entre os documentos, destacam-se entrevistas publicadas com os integrantes da Comissão de Redação do ECA, a Ata da CPI Febem (1998); Coletânea de Resoluções do Conselho estadual de São Paulo (Condeca) de 1995-2005; Resolução Condeca (1999); Notícias de jornal sobre os confrontos com a Febem (2003), Ata e Resolução do Fórum Estadual sobre o confronto com a Febem; documentos sobre a trajetória pessoal de ativistas do movimento DCA, ofícios da "Articulação" que foram enviados à prefeitura de São Paulo e ao Poder Judiciário: Departamento de Execuções da Infância e Juventude de São Paulo (DEIJ). 
Para sistematizar os achados da pesquisa, organizamos as informaçóes nos três momentos ou ciclos da luta pela política DCA e socioeducativa.

Em cada um desses ciclos identificamos aspectos que mostram a inter-relaçâa continuada entre Estado e movimento: os atores societais que constituem o movimento DCA em cada ciclo, os atores institucionais e os ativistas que "transitaram" ocupando lugares na sociedade e no Estado, em momentos distintos ou simultaneamente, conforme revelam os quadros 1 e 2 .

Quadro I - Aspectos da inter-relação entre Estado e movimento

\begin{tabular}{|c|c|c|c|}
\hline \multirow{2}{*}{$\begin{array}{l}\text { Momentos X inter-relação } \\
\text { entre Estado e movimento }\end{array}$} & \multicolumn{2}{|c|}{ Atores } & \multirow{2}{*}{$\begin{array}{l}\text { Ativistas "em } \\
\text { trânsito" }\end{array}$} \\
\hline & Societais & Estatais & \\
\hline $\begin{array}{l}\text { Ciclo de construção do } \\
\text { ECA }\end{array}$ & $\begin{array}{ll}\text { - } & \text { MNMMRua } \\
\text { - } & \text { Pastoral do Menor } \\
\text { - } & \text { Cedecas } \\
\text { - } & \text { ANCED } \\
\text { - } & \text { ONGs } \\
\text { - } & \text { FNDCA }\end{array}$ & 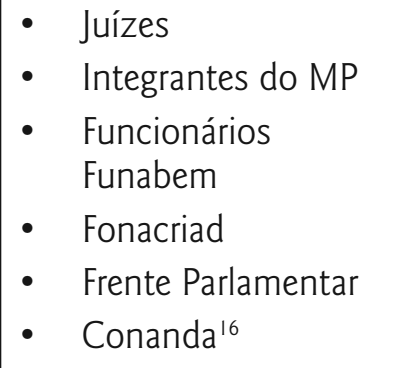 & $\begin{array}{l}\mathrm{Al} \\
\mathrm{A} 2 \\
\mathrm{~A} 3\end{array}$ \\
\hline $\begin{array}{l}\text { Ciclo de fechamento da } \\
\text { Febem/SP e construção } \\
\text { do SINASE }\end{array}$ & $\begin{array}{ll}\text { - } & \text { Cedecas } \\
\text { - } & \text { FEDCA } \\
\text { - } & \text { Mães (AMAR) } \\
\text { - } & \text { OAB } \\
\text { - } & \text { ANCED } \\
\text { - } & \text { Anistia Internacional }\end{array}$ & $\begin{array}{ll}\text { - } & \text { Conanda } \\
\text { - } & \text { Condeca } \\
\text { - } & \text { Juízes } \\
\text { - } & \text { MP } \\
\text { - } & \text { Corte da OEA }\end{array}$ & $\begin{array}{l}\text { A4 } \\
\text { A5 }\end{array}$ \\
\hline $\begin{array}{l}\text { Ciclo de construção da } \\
\text { política socioeducativa } \\
\text { em meio aberto }\end{array}$ & $\begin{array}{l}\text { - } \text { FEDCA } \\
\text { - } \text { FMDCA } \\
\text { - } \text { Pastoral do Menor } \\
\text { - } \text { Cedecas } \\
\text { - } \text { ONGs conveniadas } \\
\text { - } \text { Articulação MSE -MA }\end{array}$ & $\begin{array}{ll}\text { - } & \text { Fundação CASA } \\
\text { - } & \text { SMADS } \\
\text { - } & \text { CMDCA } \\
\text { - } & \text { Comissão de política } \\
& \text { socioeducativa do } \\
& \text { CMDCA } \\
\text { - } & \text { Ouvidoria da } \\
& \text { Defensoria }\end{array}$ & $\begin{array}{l}\text { A4 } \\
\text { A5 } \\
\text { A6 }\end{array}$ \\
\hline
\end{tabular}

Fonte: Elaborado pela autora.

16 Os Conselhos nacional (Conanda), estadual (Condeca) e municipal (CMDCA) são atores na interface socioestatal, aqui colocados na coluna "Atores Estatais" para simplificar a tabela. 


\section{Quadro 2 - Ativistas que transitaram ${ }^{17}$ entre lugares} no Estado e no Movimento

\begin{tabular}{|l|l|}
\hline Al & Juiz, Procurador de Justiça do MP do Estado de São Paulo, redator do ECA. \\
\hline A2 & Juiz e desembargador do Tribunal de Santa Catarina. \\
\hline A3 & Procurador do Ministério Público de São Paulo. \\
\hline A4 & Cedeca SP, Articulação MSE-MA, Secretaria Municipal de Direitos Humanos/SP. \\
\hline A5 & Cedeca SP, Articulação MSE-MA, Secretaria Municipal de Assistência Social/SP. \\
\hline A6 & Coordenador de MSE MA, Articulação MSE-MA, Defensoria pública/SP. \\
\hline
\end{tabular}

Fonte: Elaborado pela autora.

A partir desta sistematizaçáo dos achados da pesquisa, nos voltamos ao objetivo de caracterizar distintos repertórios de interaçáo socioestatal que se destacaram nos três momentos ou ciclos analisados.

\section{Repertórios de interação socioestatal}

Colocando o foco na análise dos repertórios de ação coletiva (TILLY, 2010; TARROW, 2009; ABERS; SERAFIM; TATAGIBA, 2014) e nas categorias formuladas por estas autoras, buscamos identificar diferentes tipos de repertórios de interação no movimento DCA.

\section{I Protestos e confrontos no âmbito da sociedade e do Estado}

Os "repertórios de confronto" (TILLY, 1992, p. 7 apud TARROW, 2009, p. 51) estão presentes no movimento DCA quando luta contra o "paradigma menorista" e denuncia as violaçôes de direitos das crianças e dos adolescentes nas instituiçóes menoristas.

O movimento MMRua surge de uma ruptura com uma forma de organização com iniciativa institucional, as reunióes do projeto "Alternativas Comunitárias de Atendimento a Meninos e Meninas de Rua”, criado nos anos 1980 por técnicos de organizaçóes governamentais nacionais e internacionais ${ }^{18}$.

170 trânsito pode ocorrer em momentos distintos como no caso dos ativistas $A 4$, $A 5$ e $A 6$, ou em um mesmo momento, como os casos $A$ I, $A 2$ e $A 3$. Neste caso, podemos falar mais propriamente em intersecção entre Estado e movimento, mas esta intersecção também ocorre quando o trânsito se dá em momentos distintos.

I8 0 movimento surge de uma ruptura com o Projeto 'Alternativas Comunitárias de Atendimento a Meninos e Meninas de Rua', criado nos anos 1980 por técnicos do UNICEF (Fundo das Nações Unidas para a Infância), 
Surge com amplas assembleias nacionais e uma forte carga contestatória e de publicização de denúncias e propostas políticas. Outro momento importante de mobilizaçáo nacional e denúncia das instituiçóes menoristas foi a Campanha "Criança Constituinte" que desencadeou momentos fortes de negociação com o Congresso Nacional no período Constituinte.

As denúncias se constituem em repertório de contestação e confronto no movimento DCA ao longo dos três ciclos: são denúncias das instituiçóes menoristas durante as lutas pelo ECA e também depois dele, no ciclo de protestos e rebelióes na Febem/SP, muitas vezes consolidadas nas visitas de fiscalização realizadas por ONGs locais, nacionais e internacionais. Pudemos identificar essas denúncias, também, na ação dos Conselheiros Tutelares e Conselhos de Direitos e nas açóes de apoio dos Fóruns DCA aos Conselhos Tutelares em São Paulo. Esses repertórios de protesto se traduziram, muitas vezes, em Campanhas desde a Constituinte até as Campanhas pela erradicação do trabalho infantil, e contra a exploração sexual de crianças e adolescentes.

Outro exemplo de confronto na relação com o Estado tem sido a apresentação às Nações Unidas de Informes Alternativos ao informe oficial de monitoramento sobre a Convenção internacional dos Direitos da Criança. Esses informes foram elaborados pela sociedade civil em vários países. No Brasil, foram elaborados pela $\mathrm{ANCED}^{19}$, com denúncias que se confrontam com os informes oficiais do governo brasileiro (ALBUQUERQUE, 2007).

O repertório do movimento DCA envolve tanto açóes contestatórias como ações pacíficas. O movimento herda, por exemplo, repertórios típicos das "pastorais" religiosas, com sua metodologia da educação popular. Destacam-se campanhas educativas (Campanha da Fraternidade sobre o menor abandonado, em 1987), os encontros de estudos e de articulaçáo onde houve a sistematização das metodologias dos "educadores de rua" e onde se formularam as primeiras diretrizes da "Doutrina da Proteção Integral", conhecida como o "paradigma garantista".

Por outro lado, os repertórios de confronto frequentemente se articulam com repertórios propositivos, que envolvem negociação e diálogo com o Estado.

da FUNABEM e da SAS (Secretaria de Ação Social, do Ministério da Previdência e Assistência Social), para mapear as experiências inovadoras de "educação de rua" em todo o país. Ver Santos (1994).

19 Consulte mais informações no site: <http://www.anced.org.br/> 
As denúncias e os protestos contra as práticas menoristas sempre se colocaram como formas de abrir negociaçóes com o poder público pela suspensão dessas práticas e pela construção de novas políticas de garantia de direitos. Exemplos importantes foram as mobilizaçóes do MNMMRua e a Campanha "Criança Constituinte" que conseguiram pautar o Congresso Nacional, criando Grupos de Trabalho (GTs) que introduziram a agenda garantista na Constituição e depois na elaboraçáo do ECA. Assim como no caso de outros movimentos sociais, o peso dessas mobilizaçóes provocou uma série de "negociaçôes a quente ${ }^{20 "}$ que conseguiram neutralizar, em certa medida, os setores conservadores no Congresso e outros órgãos públicos.

O mesmo ocorreu no ciclo de lutas que levou à extinção da Febem/SP. Nesse caso, os atores societais mais fortemente envolvidos foram os próprios adolescentes rebelados, a Associação de mães (AMAR), os Cedecas, o Fórum estadual DCA, outras ONGs de São Paulo e até mesmo a ONG Anistia Internacional. Mobilizaçôes nacionais e internacionais provocaram a constituição de um Grupo de Trabalho (GT) envolvendo atores societais e estatais, entre os quais funcionários da própria instituição e dos poderes executivo e judiciário do Estado de Sáo Paulo, que redefiniu a instituição. A presença de atores socioestatal como o Conselho estadual (Condeca) foi fortemente ativa nesse episódio (LONGO, 2010).

Nos movimentos que lutam por avanços nas políticas públicas, vemos uma ressignificação das açóes de confronto, na medida em que muitas vezes essa forma de ação se articula com outros repertórios de negociação com o Estado: ao confronto, segue a negociação. Como assinalado por Abers, Serafim e Tatagiba (2014), as açóes de confronto são muitas vezes utilizadas como forma de abrir ou desemperrar negociaçôes, as quais envolvem momentos mais conflituosos com atores estatais opositores e açóes de colaboraçáo com atores que integram coalizóes centradas em um mesmo paradigma de crenças. Essas negociações ocorrem na relaçáo com o poder público (Poder Executivo, Parlamento (Congresso Nacional), Poder Judiciário), no interior de espaços participativos ad hoc como os GTs para elaboração de políticas, e mediante a

20 Essa expressão é utilizada pelo Movimento Sem Terra (MST) para descrever os processos de negociações sobre a política agrícola que todo ano vem sendo precedidos de "jornadas de luta" com a finalidade de pautar o governo e abrir negociações em condições mais favoráveis. Ver: Abers, Serafim e Tatagiba (2014). 
participação institucional nas instituições participativas (IPs), conforme veremos a seguir.

\subsection{Ocupação de cargos no Estado e militância múltipla}

O movimento DCA sempre foi uma articulação heterogênea de atores societais entre os quais o MNMMRua, as ONGs, as organizaçóes profissionais, os Fóruns. Desde a origem do movimento existe a presença de profissionais que atuam no Estado ${ }^{21}$ junto a crianças e adolescentes, como juízes, promotores, defensores públicos, médicos, psicólogos, assistentes sociais e educadores, bem como das respectivas organizaçóes profissionais.

Em diversos momentos, pessoas que ocupavam cargos no Estado foram ativistas do movimento DCA, participando especialmente do Grupo de Trabalho (GT) que elaborou os artigos 227 e 228 da Constituição, da Comissão de Redação do $\mathrm{ECA}^{22}$, dos GTs que elaboraram as propostas para o Sinase e para a municipalização da política socioeducativa em meio aberto.

Entre os ativistas que transitaram entre lugares no Estado e no movimento social que observamos na Tabela 2, nota-se algo semelhante ao que Mische (1997, p. 144) denomina de "militância múltipla" e que é também apontado por Silva e Oliveira (2011) como exemplos de trânsito institucional ou intersecção entre Estado e movimento. Os ativistas A1 até A3 ocuparam cargos no Poder Judiciário e/ou no Ministério Público e simultaneamente em espaços de interação socioestatal (GTs e outros espaços de negociação) do movimento, em momentos de elaboração e negociaçáo de políticas de Direitos da Criança e do Adolescente.

Ao contrário dos casos analisados por estes autores, esse trânsito entre a ação no Estado e no movimento não ocorreu em funçáo de compartilhamento de projetos políticos partidários, mas de um projeto político que se expressa no "paradigma garantista". O mesmo ocorreu em relação ao trânsito do ativista

21 A ocupação de cargos no Estado é uma categoria-chave na análise de Dowbor (2012) sobre os repertórios de ação coletiva do movimento sanitarista no Brasil.

22 Entre os integrantes da Comissão de Redação do ECA, estavam os procuradores do Ministério Público de São Paulo Munir Cury e Paulo Afonso Garrido de Paula, os juízes Antônio Fernando do Amaral e Silva (Tribunal de Santa Catarina) e Liborne Bernardino Siqueira (juiz de Menores do Rio de Janeiro), Benedito Rodrigues dos Santos (MNMMRua), Antonio Carlos Gomes da Costa (educador da Febem/MG e integrante do Unicef), Irmã Maria do Rosário Leite Cintra e Ruth Pistori, da Pastoral do Menor. 
A6, de uma organização do movimento para a Defensoria Pública de São Paulo. Esses ativistas não ocuparam cargos no poder executivo.

Já no caso dos ativistas A4 e A5, temos o trânsito entre lugares ocupados no movimento e no poder executivo municipal, mediados por uma militância múltipla no Partido dos Trabalhadores, que governava o Município de São Paulo em dois momentos especiais de luta pela política garantista. O primeiro é o caso do integrante de um dos Cedecas de Sáo Paulo, fundador da Articulação MSE-MA (na época dos convênios com a Febem) e que coordenou a construção do Sistema de Proteção Social à Criança, ao Adolescente e ao Jovem, na Secretaria de Assistência Social de São Paulo (SAS), nos anos 2001 a 2004, período em que foram desenhados e implementados os Projetos-piloto do atendimento socioeducativo em meio aberto. Outro fundador da Articulação MSE-MA, integrante do mesmo Cedeca, foi Coordenador de Políticas para Crianças e Adolescentes da Secretaria Municipal de Direitos Humanos e Cidadania e presidente do CMDCA em 2013 e 2014. Nesses casos, a ocupação de espaços no Estado e no movimento se deu em momentos distintos. No entanto, em todos eles esse trânsito promoveu uma interação entre Estado e movimento, facilitando o acesso do movimento ao Estado.

\subsection{Participação institucional - o controle social na política socioeducativa}

A partir da promulgaçáo do ECA o movimento DCA inicia uma forma de atuaçáo institucional mais permanente e continuada, que Abers, Serafim e Tatagiba (2014) denominam "participação institucional" - a participação nos Conselhos e Conferências de Direitos das Crianças e Adolescentes, desde o nível nacional até o municipal, e mesmo em espaços regionais dentro de cidades como São Paulo (pré-Conferências) que vem sendo analisada por extensa literatura ${ }^{23}$. O funcionamento dessas instituiçóes participativas (IPs) não se diferencia da média dos avanços e problemas experimentados nas outras áreas, com algumas especificidades.

23 A ação institucional dos movimentos em instituições participativas (IPs) como os Conselhos e as Conferências de direitos e de políticas públicas é alvo de extensa literatura que a descreve e critica frente a vários aspectos como a representatividade e a eficácia. Ver Nastari (2006), Pires (20II), Abers, Serafim e Tatagiba (20I4), swacko (2012), entre muitos outros. 
Os Conselhos e as Conferências, bem como as organizaçóes da sociedade civil, são responsáveis, segundo a legislação (Artigos 227 e 204 da Constituição, ECA, Resoluçóes 113 e 119 do Conanda), por exercer o controle social sobre a política DCA, em todas as suas fases: a formação da agenda pública, a proposição de normativas e instrumentos de política pública, a execução, o monitoramento e a avaliação das políticas (ALBUQUERQUE, 2012).

O Conanda desempenha papel central na construçáo da política DCA através de suas Resoluçôes, que delineiam a própria estrutura participativa e as atribuições dos Conselhos e Conferências, bem como o desenho e funcionamento do Sinase e os Planos Nacionais das respectivas políticas ${ }^{24}$. O Condeca desempenha papel especialmente relevante na extinção da Febem/SP. O CMDCA desempenha papel relevante no terceiro ciclo analisado, a definição da política municipal socioeducativa.

Além destas instituiçóes participativas mais formalmente ligadas ao controle social, cuja análise náo vamos aprofundar aqui, destaca-se a participação institucional em duas fases do ciclo da política DCA: a formulação e a execução da política.

\subsection{Participação na formulação da política - os GTs e as coalizões}

Destacamos, neste tópico, uma forma de participação institucional que se tornou relevante mesmo antes da criação dos Conselhos e das Conferências de Direitos das Crianças e Adolescentes - os Grupos de Trabalho (GTs) que, assim como as IPs mais estudadas, são importantes nas negociaçóes que criaram as políticas de direitos nessa área.

Estes GTs, criados para elaboração e proposição de novas políticas, foram e são compostos por atores societais e institucionais envolvidos na política. Recorremos aqui aos conceitos das teorias neoinstitucionalistas de políticas públicas, de "comunidades de políticas" e de "coalizóes de defesa" - que articulam atores distintos em torno de conjuntos de crenças e propostas para uma dada política.

24 O Conanda define diretrizes para a Política Socioeducativa e também para as políticas de adoção, convivência familiar e comunitária e de combate à exploração sexual de crianças e adolescentes. 
Nota-se que, em meio ao conjunto de atores que influenciam a política de direitos da criança e do adolescente, e em particular a política socioeducativa, constitui-se no Brasil uma coalizão de atores, que compartilham crenças, tanto de nível mais profundo e paradigmático (o "paradigma garantista") como aquelas mais operacionais, relativas às políticas de direitos que se consolidam desde então. Essa coalizão se conforma articulando "comunidades de especialistas" e também lideranças sociais e políticas, protagonistas e "empreendedoras" que tomam a iniciativa de coordenar esforços e trabalhar em conjunto para atingirem objetivos comuns. Ela é integrada por entidades internacionais (com destaque para o Unicef ${ }^{25}$ ), nacionais, estaduais, e locais. Estão presentes atores societais populares como a Pastoral do Menor, o Movimento MNMMRua, os Cedecas e outras ONGs nacionais e locais, além de associaçóes profissionais, como a Sociedade Brasileira de Pediatria, a OAB e a ABMP. É integrada, ainda, por atores estatais, destacando-se setores dos Poderes Legislativo, Executivo e Judiciário, além do Ministério Público, que aderem ao "paradigma garantista".

A identidade de crenças vai se conformando desde as primeiras denúncias sobre as instituiçóes menoristas, mas adquire desenho mais nítido na formação de Frentes de defesa da criança e do adolescente e dos Grupos de Trabalho (GTs) para a elaboração de propostas para a Constituição e o ECA. As crenças compartilhadas projetam, portanto, "uma imagem de como o subsistema de política deveria ser". Além de compartilhar crenças, os atores começam a se coordenar, adquirindo um "comportamento estratégico" que ajuda a "unir aliados e dividir adversários" e a trabalhar em conjunto para a fim de atingir objetivos semelhantes (SABATIER; WEIBLE, 2007, p. 195 apud DOWBOR, 2012, p. 75). É o que se pode notar nas coalizóes formadas para a redaçáo dos artigos 227 e 228 da Constituiçáo Federal e do ECA (BRASIL, 1988, 1990a).

A coalizão formada para redigir esses artigos constitucionais nasceu da então Associação de Curadores da Infância, hoje ABMP. Para redigir a proposta, ela buscou fundamentos no anteprojeto da Convençáo Internacional dos Direitos da Infância, articulando-se com os atores societais do movimento DCA e mobilizando o país para a coleta de assinaturas para a emenda

25 UNICEF é o Fundo das Nações Unidas para a Infância, que atua no Brasil através de vários escritórios. 
constitucional "Criança Constituinte". A Comissão de Redação do ECA nasceu dessa coalizão e foi integrada por juristas de varas da Infância e Juventude e do Ministério Público, por representantes do MNMMRua e da Pastoral do Menor, e buscou negociaçóes com o então Ministro da Justiça, diretores das Febems, secretários de educação, entre outros.

De forma semelhante, e com muitos dos mesmos atores, foram compostos os Grupos de Trabalho (GTs) que elaboraram as propostas para o Sinase, desde antes de 2006 até 2012, no que descrevemos como o segundo ciclo de mobilização do movimento DCA. No momento atual, um grupo de trabalho integrado pela SMADS e pela Articulação MSE-MA coordena a elaboração do Plano Municipal de Atendimento Socioeducativo. Em todos esses casos, um setor do movimento integra, junto com atores estatais, um grupo de trabalho formado para a elaboração da política de direitos.

\subsubsection{Participação na execução da política}

No terceiro ciclo, focado no Município, os atores societais (por exemplo, Pastorais, Cedecas e Fóruns) foram importantes no processo de descentralização da política socioeducativa e de reivindicação da nova política municipal, mas tornaram-se cada vez mais presentes os vínculos institucionais, destacando-se a formalização das entidades de atendimento e sua participação na implementação da política socioeducativa ${ }^{26}$. Em São Paulo, tais entidades se vinculam com o Município através de convênios para a execução das Medidas Socioeducativas em Meio Aberto.

A formalização e a vinculação ao Estado, são muitas vezes, vistas pelo próprio movimento como ameaça à sua autonomia, necessária para as críticas e reivindicaçôes ao poder público (FNDCA, 2010, p. 21-41; ALBUQUERQUE, 2012). Apesar dessas limitaçóes, a presente pesquisa identificou a formação de uma articulação de entidades executoras, que se constitui em um espaço capaz do exercício do controle social. Observamos a continuada atuaçáo da Articulação dos Serviços de Medidas Socioeducativas em Meio Aberto (Articulação MSE - MA) na crítica e reivindicação de melhorias na política socioeducativa,

26 As entidades de atendimento à criança e ao adolescente são ativas na filantropia no Brasil há séculos. A partir da Constituição e do ECA, elas se integram formalmente à política e ao Sistema de Garantia de Direitos da Criança e do Adolescente, o que é explicitado na Resolução no II 3 do Conanda. Em São Paulo, esta presença é ainda maior do que nos demais municipios brasileiros. 
buscando compatibilizá-la com os parâmetros do paradigma de garantia de direitos. A atuação dessa articulação se destacou no processo de municipalização, entre 2002 e 2005, com forte protagonismo na criação de Projeto Piloto para a política socioeducativa que foi negociado com a Secretaria Municipal de Assistência Social (SAS) e a Secretaria Nacional de Direitos Humanos (ALBUQUERQUE; BOTELHO; OLIVEIRA, 2013).

Nesse sentido, essa atuação contínua, com críticas e sugestôes à política socioeducativa, observadas nas reuniōes da Articulação MSE - MA e transmitidas nas reunióes e nos documentos enviados para o executivo municipal (SMADS), o Poder Judiciário (DEIJ - Departamento de Execuções da Infância e Juventude e Defensoria Pública) e o Ministério Público.

Desde 2013, a Articulação MSE - MA participa em um grupo de trabalho para a elaboração do Plano Municipal de Atendimento Socioeducativo. Por outro lado, a essa articulaçáo realizou uma pesquisa para caracterizar as condiçóes de execução da política socioeducativa. O documento final apresenta um diagnóstico contundente sobre essas condiçôes (ALBUQUERQUE et al., 2014).

Vemos, assim, que ao lado da participação na execução da política e assumindo o papel de uma organizaçáo integrante do movimento DCA, a Articulação MSE - MA participa do controle social sobre a política socioeducativa, com propostas, críticas e avaliaçóes. Essa participaçáo é limitada pelo vínculo de conveniamento entre as ONGs que a integram e o Município. Essa limitação é percebida na linguagem polida utilizada nos documentos analisados.

Em muitos casos, entretanto, as sugestôes e críticas são incisivas, especialmente em relação às polícias e ao Poder Judiciário. A referida pesquisa denuncia, também, a precariedade da forma como o Município transfere às ONGs sua responsabilidade legal pela política, especialmente em três aspectos: falta de comando e capacitação dos gestores dos CREAS para a política socioeducativa; verbas insuficientes para a implementação da política, o que obriga as ONGs a buscarem recursos na sociedade; e náo assumir seu papel na articulação da rede de serviços públicos (como educação, saúde, trabalho e lazer) indispensáveis para a execução das Medidas Socioeducativas (ALBUQUERQUE et al., 2014). 
Dentro do tipo de interação socioestatal no caso do movimento DCA, denominado por Abers, Serafim e Tatagiba (2014) como participação institucional, estacamos sua participação em dois momentos do ciclo dessa política: sua formulação e sua execução. $\mathrm{Na}$ formulação da política, estão os Grupos de Trabalho (GTs) que se constituem dentro de coalizóes integradas pelo movimento social e atores institucionais. Destacamos, ainda, a participaçáo de um setor do movimento na execuçáo da política pública socioeducativa que, pelo menos no caso estudado, se mostra compatível com o exercício do controle social sobre a política.

\section{Dos lobbies à articulação entre controle social e estatal}

Entre as categorias desenvolvidas por Abers, Serafim e Tatagiba (2014, p. 336)estáo os "lobbies no parlamento", que ocorrem especialmente nos períodos de lutas pela aprovação de uma nova legislação.

No caso da política socioeducativa, as denúncias do movimento sobre as instituiçóes menoristas articulam-se com açóes do parlamento, órgão institucional de controle sobre a política pública, dando origem a CPIs e CEIs (PEREIRA, 1996, p. 63) e à Frente Parlamentar pelos Direitos da Infância e Juventude, que atuou na aprovaçáo do ECA (LONGO, 2010, p. 10). Nas lutas pela extinçáo da Febem/SP, houve outra CPI - a CPI da Febem, que atuou de 1997 a 1999. Além desses momentos, o movimento se articula continuamente com comissóes parlamentares voltadas à temática da infância, nas Assembleias Legislativas e nas Câmaras Municipais de Vereadores.

Para além do lobby do movimento junto ao parlamento, podemos comentar aqui sobre uma articulação entre o controle social, realizado pelos atores do movimento social, e o controle público estatal, que é uma atribuição constitucional (artigos 70 a 75 da Constituição Federal) realizada pelo Parlamento, Tribunal de Contas, Poder Judiciário, Ministério Público entre outros $^{27}$. O controle estatal é ratificado para a política DCA no artigo $21 \mathrm{da}$ Resoluçáa no 113 do Conanda. Em diversos momentos, percebemos uma ação articulada entre o controle social exercido pelo movimento social e a ação exercida pelos órgãos institucionais de controle estatal.

27 Ver "O controle público sobre a política socioeducativa: a relação entre o controle estatal e o controle social" (Alonso, 20/3). 
Além das citadas CPIs, destaca-se como controle estatal a ação do Tribunal de Contas da União e do Conselho Nacional de Justiça, cujos Relatórios (TCU, 2005 e 2009; CNJ, 2012) analisam a situação da política socioeducativa em todos os estados da federação, denunciando situaçóes de grave desrespeito aos direitos humanos no sistema socioeducativo e definindo, por meio de acórdão, mudanças na política a serem implementadas pelo Poder Executivo e Judiciário.

Destacamos, ainda, a fiscalização realizada pela Corte Interamericana de Direitos Humanos da OEA, no contexto das lutas pela extinçáo da Febem (ALBUQUERQUE, 2012).

No plano municipal, destaca-se a relação continuada entre o Departamento de Execuçóes da Infância e Juventude (DEIJ), a Secretaria que coordena a política socioeducativa (SMADS) e a Articulação MSE-MA. Como se pode verificar em Ofício do ano de 2012, da articulaçáo ao DEIJ, verifica-se que este órgáo do Judiciário requisita ao movimento social informaçóes necessárias para o exercício do controle que deve exercer sobre o executivo municipal. Por outro lado, a Articulação MSE-MA apresenta, neste e em outros documentos, avaliaçóes e críticas à política municipal socioeducativa (ALBUQUERQUE et al., 2014).

Devemos evidenciar, ainda, a ação da Ouvidoria da Defensoria Pública do Estado de São Paulo. A Defensoria é órgão do Poder Judiciário e sua Ouvidoria é aberta à participação popular e vinculada explicitamente ao controle público estatal e social ${ }^{28}$. A Ouvidoria tem sido acionada pela Articulaçáo MSE-MA para análise crítica das audiências judiciais a que são submetidos os adolescentes que cumprem Medidas Socioeducativas, entre outros aspectos da política. Neste caso, assim como em outros, o vínculo entre o controle social e estatal é mediado por um ativista que transita entre o movimento e o Estado, facilitando a interação entre eles.

Dado o exposto, a interação com o parlamento vai além do lobby, o que dá lugar a uma nova chave de leitura: o controle público sobre a política, onde se articulam o controle social e estatal sobre a política. Essa articulação ocorre

28 A Ouvidoria da Defensoria Pública do Estado de São Paulo é um órgão de controle público externo entre as instituições do Sistema de Justiça. A pesquisadora presenciou reunião conjunta entre Ouvidoria da Defensoria Pública e a Articulação MSE- MA em 25 de março de 20/4. Ver: <http://www.defensoria.sp.gou.br/dpesp>. 
na relação entre o movimento e outros espaços legais de controle público sobre a política socioeducativa.

\section{Reflexões finais: a interdependência entre Estado e sociedade e o lugar do movimento na construção de uma nova política de direitos}

Este artigo apresenta elementos empíricos que buscam revelar a inter-relação entre movimento social e Estado. Essa perspectiva é importante especialmente no Brasil, onde um número considerável de movimentos sociais tem atuado fortemente na construção de novos direitos e de novas políticas públicas que os garantam. É o caso do movimento DCA e sua incidência nas políticas de Direitos da Criança e do Adolescente e, em particular, na política socioeducativa.

A pesquisa mostra que a face institucional do movimento, frequentemente vista como um defeito, é uma dimensáo constitutiva, na medida em que luta por direitos e políticas públicas. Uma "abordagem relacional no estudo dos movimentos sociais" permite desocultar uma "face" (SILVA; OLIVEIRA, 2011, p. 88) que se necessita explicitar e analisar para enxergar o movimento social como um dos atores relevantes na formação e implementação da política pública.

No caso da política DCA, a participação do movimento ocorre na inter-relação com atores estatais que integram o conjunto de atores nela implicados: Poderes Executivo, Legislativo e Judiciário, Ministério Público. Destacam-se novas categorias na fronteira entre as análises sobre movimentos e políticas públicas, tipificando repertórios de interação socioestatal do movimento e sua atuação em coalizóes de defesa do "paradigma garantista”.

Examinamos, no movimento DCA, os tipos de repertórios de interação apontados por Abers, Serafim e Tatagiba (2014).

Vimos que os protestos ou confrontos são ressignificados na medida em que se articulam com o diálogo propositivo nas negociaçóes com o poder público em torno da formulação ou implementação da política de Direitos da Criança e do Adolescente (política DCA). Os confrontos do movimento com o poder público favoreceram o início ou a continuidade das negociaçóes durante a Constituinte, na elaboração do ECA, do Sinase etc. 
$\mathrm{Na}$ categoria da participação institucionalizada, além das IPs legalmente instituídas, como os Conselhos e as Conferências de políticas públicas, destacam-se outras formas de controle social especialmente voltadas às fases de formulação e de execução da política. $\mathrm{Na}$ fase de formulação da política, atuam os Grupos de Trabalho (GTs). Eles revelam a constituição de coalizóes entre atores societais e estatais, articuladas em vista da construção de políticas públicas que concretizem o "paradigma garantista" dos direitos da infância um conjunto de crenças que se expressam e se operacionalizam na construção das políticas garantistas.

Destaca-se, ainda, o trânsito de ativistas entre espaços societais e estatais no interior destas coalizóes, o que favorece muitas vezes a consolidação das mesmas.

Também analisamos a participação de um setor do movimento na fase de execução da política pública. No caso da política socioeducativa, em São Paulo, destaca-se a atuaçáo de entidades da sociedade civil que participaram ativamente do movimento DCA ao longo de sua história, na execuçáo da política, mediante convênios com o Município. Este lugar e papel duplo, na execução e no controle social da política, é avaliado por integrantes do movimento como um problema - pelo risco de cooptação e subordinaçáo aos interesses do Estado. No entanto, a perspectiva que incorpora a face institucional do movimento permite ver que a constituiçáo de uma articulação entre as entidades executoras como parte do movimento DCA possibilita uma atuação crítica e propositiva no controle social sobre a política. A interação com o parlamento vai além do lobby, o que dá lugar a uma nova chave de leitura: o controle público sobre a política.

A participação do movimento no controle social ocorre especialmente nos Conselhos e nas Conferências que definem a política DCA. No entanto, o controle público é também constituído pelo controle estatal interno e externo sobre a política pública (artigos 70 a 75 da Constituição Federal). O controle estatal, ratificado para a política DCA no artigo 21 da Resolução no 113 do Conanda, deve ser exercido pelo Poder Legislativo, Judiciário e pelo Ministério Público.

A pesquisa aponta uma articulação entre instituiçóes de controle social e de controle estatal sobre essa política. Ela se revela na articulação entre o 
movimento e as CPIs, que investigaram violaçóes aos direitos humanos nas instituições marcadas pelo "paradigma menorista", bem como na utilização pelo movimento das fiscalizaçóes e denúncias realizadas pelo TCU e CNJ. Revela-se ainda nas articulaçóes entre o movimento e a Defensoria Pública de São Paulo com vistas à melhor atuação do Sistema de Justiça na política socioeducativa. Essa articulação ocorre na relação entre o movimento e os diversos espaços legais de controle público sobre a política socioeducativa. Essa perspectiva aponta para a importância de não se pensar o controle social isoladamente, mas pensá-lo como integrante do "controle público" com sua articulação com os institutos legais de controle estatal.

Este artigo tipifica repertórios de interação entre movimento e Estado, característicos da incidência do movimento DCA na política socioeducativa: o confronto como abertura de negociaçóes, a participação na elaboração da política através de GTs e também na execução da mesma, o trânsito de ativistas entre Estado e sociedade, que facilita as relaçóes entre ambos, e a articulação entre controle social e estatal, que dá origem à noção de controle público.

Como afirmam Gurza Lavalle e Szwako (2015, p. 10), tem sido crucial “[...] esquadrinhar os padróes da interdependência entre atores sociais e Estado, a constituição e/ou consequências desses padróes, bem como as mudanças na natureza dessa interdependência ao longo do tempo" e fazer a crítica à "[...]compreensão dicotômica da relação entre Estado e sociedade civil”. Já Dagnino (2011, p. 124) afirma que "[...] sociedade civil e Estado são sempre mutuamente constitutivos".

Analisar padróes de interdependência entre atores sociais e Estado é essencial para fugir da avaliaçáo simplista de que a interação entre Estado e movimento leva à burocratizaçáo e cooptaçáo, e analisar a complexidade da interaçáo socioestatal em seus diferentes repertórios. Náo se trata de negar os riscos de burocratização e cooptação, os quais certamente estáo presentes - seja quando o repertório é mais confrontacional seja quando se abrem as interações de negociação e proposição. Esses riscos, conflitos e essas tensões permanecem como desafios de pesquisa para outros trabalhos. Tratou-se aqui de examinar, com mais cuidado, as diferentes formas de interaçáo para compreender o lugar e o papel do movimento social na conquista de direitos no cenário de construção democrática que se abriu no pós 1988. 


\section{Referências}

ABERS, R.; BÜLOW, M. V. Movimentos sociais na teoria e na prática: como estudar o ativismo através da fronteira entre Estado e sociedade. Sociologias, Porto Alegre, ano 13, n. 28, p. 52-84, set./dez. 2011.

ABERS, R.; SERAFIM, L.; TATAGIBA, L. Repertórios de interação Estado-Sociedade em um Estado heterogêneo: a experiência na era Lula. Dados - Revista de Ciências Sociais, Rio de Janeiro, v. 57, n. 2, p. 325-357, 2014. Disponível em: <http://www.scielo.br/pdf/dados/v57n2/a03v57n2. pdf $>$. Acesso em: 20 jul. 2013.

ALBUQUerQue, M. C. A. A participação da sociedade na redefinição de políticas de direitos. Os direitos da Infância e o direito à moradia em países do Cone Sul na virada para o Século XX. 2007. Tese (Doutorado em Integração da América Latina) Programa de Pós-Graduação Interunidades e Integração da América Latina (Prolam). Universidade de Sáo Paulo, PROLAM/ USP, dez. 2007.

“Eppur si muove...”. Os movimentos sociais e a construção da democracia no Brasil.

Dissertação (Mestrado em Ciência Política) Programa de Pós-Graduação em Ciência Política do Instituto de Filosofia e Ciências Humanas - Universidade Estadual de Campinas, Campinas: UNICAMP, 1997.

. Novos atores e repertórios de ação no movimento pelos direitos do adolescente: repensando a institucionalização. Serviço Social em Revista, v. 15, n. 1. Londrina: Universidade Estadual de Londrina, 2012.

AlbUQUerQUe, M. C. A.; BOTELHO, D.; OliVeirA, A. A municipalização das medidas socioeducativas em meio aberto em São Paulo (SP) e Pouso Alegre (MG). Revista Brasileira Adolescência e Conflitualidade, n. 9, p. 25-47, São Paulo, 2013.

ALBUQUERQUE, M. C. A. et al. Medidas socioeducativas em conflito: um diagnóstico a partir das equipes técnicas e adolescentes do meio aberto. In: VI ENCONTRO DE PÓS-GRADUAÇÃO E PESQUISA ADOLESCÊNCIA E CONFLITUALIDADE. Universidade Anhanguera de São Paulo. São Paulo: nov. 2014.

ALONSO, A. P. G. O controle público sobre a política socioeducativa: a relação entre o controle estatal e o Controle Social. 2013. Dissertação (Mestrado Profissional Adolescente em Conflito com a Lei - MPACL) - Universidade Bandeirante Anahanguera, São Paulo: Unian, 2013.

ALMEIDA. C. C. R. Sociedade civil, diversificação de atores e de modalidades de ação. Em Debate, Belo Horizonte, v. 3, n. 4, p. 8-13, dez. 2011. Disponível em: <http://www.opiniaopublica.ufmg. br/emdebate/Artigo_Carla.pdf>. Acesso em: 20 jul. 2013. 
ANCED. Disponível em: <http://www.anced.org.br>. Acesso em: 21 jul. 2013.

BRASIL. Conselho Nacional de Justiça. Panorama Nacional. A execução das medidas socioeducativas de internação. Programa Justiça ao Jovem. 2012. Disponível em: <www.cnj.jus. br>. Acesso em: 17 dez. 2013.

Constituição (1988). Constituição da República Federativa do Brasil de 1988. Disponível em: <http://www.planalto.gov.br/ccivil_03/constituicao/constituicao.htm>. Acesso em: 15 dez. 2013.

. Lei no 8.069, de 13 de julho de 1990a. Dispóe sobre o Estatuto da Criança e do Adolescente e dá outras providências. Diário Oficial da Uniáo, Brasília, DF, 16 jul. 1990a. Disponível em: <http://www.planalto.gov.br/ccivil_03/leis/18069.htm>. Acesso em: 22 jul. 2013.

Lei no 8.080, de 19 de setembro de 1990b. Dispôe sobre as condiçóes para a promoção, proteção e recuperação da saúde, a organização e o funcionamento dos serviços correspondentes e dá outras providências. Diário Oficial da Uniáo, Brasília, DF, 20 set. 1990b. Disponível em: <http://www.planalto.gov.br/ccivil_03/leis/18080.htm>. Acesso em: 26 jul. 2013.

. Lei $\mathrm{n}^{\circ}$ 8.142, de 28 de dezembro de 1990. Dispóe sobre a participação da comunidade na gestão do Sistema Único de Saúde (SUS) e sobre as transferências intergovernamentais de recursos financeiros na área da saúde e dá outras providências. Diário Oficial da Uniáo, Brasília, DF, 28 dez. 1990c. Disponível em: <http://www.planalto.gov.br/ccivil_03/leis/18142.htm>. Acesso em: 26 jul. 2013.

Lei no 8.742, de 7 de dezembro de 1993. Dispóe sobre a organizaçáo da Assistência Social e dá outras providências. Diário Oficial da Uniáo, Brasília, DF, 8 dez. 1993. Disponível em: <http://www.planalto.gov.br/ccivil_03/leis/18742.htm>. Acesso em: 26 jul. 2013.

. Lei no 12.594, de 18 de janeiro de 2012. Institui o Sistema Nacional de Atendimento Socioeducativo (Sinase), regulamenta a execução das medidas socioeducativas destinadas a adolescente que pratique ato infracional; e altera as Leis nos 8.069, de 13 de julho de 1990 (Estatuto da Criança e do Adolescente); 7.560, de 19 de dezembro de 1986, 7.998, de 11 de janeiro de 1990, 5.537, de 21 de novembro de 1968, 8.315, de 23 de dezembro de 1991, 8.706, de 14 de setembro de 1993, os Decretos-Leis nos 4.048, de 22 de janeiro de 1942, 8.621, de 10 de janeiro de 1946, e a Consolidação das Leis do Trabalho (CLT), aprovada pelo Decreto-Lei no 5.452, de 1o de maio de 1943. Diário Oficial da União, Brasília, DF, 16 jul. 2012. Disponível em: <http://www.planalto. gov.br/ccivil_03/_ato2011-2014/2012/lei/112594.htm>. Acesso em: 23 jul. 2013.

Secretaria Especial dos Direitos Humanos (SDH/PR). Plano Nacional de Atendimento

Socioeducativo: Diretrizes e eixos operativos para o SINASE. Brasília: SDH/PR, 2013. Disponível em: <http://www.sdh.gov.br/assuntos/criancas-e-adolescentes/pdf/plano-nacional-deatendimento-socioeducativo-diretrizes-e-eixos-operativos-para-o-sinase>. Acesso em: 20 jul. 2013. 
Secretaria Especial dos Direitos Humanos (SDH). Sistema Nacional de Atendimento Socioeducativo. SINASE. Brasília: CONANDA, 2006.

Tribunal de Contas da União. Secretaria de Fiscalização e Avaliação de Programas de Governo. Relatório de Monitoramento. Programa Reinserção Social do Adolescente em Conflito com a Lei (TC n ${ }^{\circ}$ 011.261/2005-6), 2005.

CARLOS, E. Movimentos sociais e instituiçóes participativas: efeitos organizacionais, relacionais e discursivos nos padrões de ação coletiva. In: II SEMINÁRIO DISCENTE DA PÓS-GRADUAÇÃO EM CIÊNCIA POLÍTICA DA USP. São Paulo: USP, 2012.

CONSELHO ESTADUAL DOS DIREITOS DA CRIANÇA E DO ADOLESCENTE. Deliberaçóes 1994-2002. São Paulo: Condeca, 2002. Disponível em: <http://www.condeca. sp.gov.br/arquivos/Livro_Condeca.pdf>. Acesso em: 7 nov. 2013.

CONSELHO NACIONAL DE JUSTIÇA. Disponível em: <www.cnj.jus.br>. Acesso em: 23 jul. 2013.

COSTA, S. Esfera Pública, Redescoberta da Sociedade Civil e Movimentos Sociais no Brasil: uma abordagem tentativa. Novos Estudos, CEBRAP, n. 38, p. 38-52, mar. 1994.

DAGNINO, E. Civil Society in Latin America. In: Edwards, M. (Org.). The Oxford Handbook of Civil Society. Oxford: Oxford University Press, 2011.

DEFENSORIA PÚBLICA DO ESTADO DE SÃO PAULO. Disponível em: <www.defensoria. sp.gov.br/dpesp>. Acesso em: 23 jul. 2013.

DIANI, M. The concept of social movements. The Sociological Review. v. 40, n. 1, feb. 1992, p. 1-25.

DOWBOR, M. Arte da institucionalização: estratégias de mobilização dos sanitaristas (19742006). 2012. Tese (Doutorado em Ciência Política) Programa de Pós-Graduação em Ciência Política - Universidade Federal de São, São Paulo: USP, 2012.

FÓRUM NACIONAL DE DEFESA DA CRIANÇA E DO ADOLESCENTE. Incidência da sociedade civil na garantia dos direitos da criança e do adolescente. Plenária de políticas públicas. Brasília, 2010. Disponível em: <http://www.forumdca.org.br/arquivos/documentos>. Acesso em: 25 jul. 2013.

FÓRUM NACIONAL DE PREVENÇÃO E ERRADICAÇÃO DO TRABALHO INFANTIL. Disponível em: <http://www.fnpeti.org.br>. Acesso em: 25 jul. 2013.

GURZA LAVALLE, A.; SZWAKO, J. Sociedade civil, Estado e autonomia. Argumentos, contraargumentos e avanços no debate. Opiniáo Pública. Campinas. 2015. No prelo. 
KINGDON, J. W. Agendas, Alternatives, and Public Policies. New York: Harper Collins College Publishers, 1995.

KOWARICK, L. F. F. Movimentos Urbanos no Brasil Contemporâneo: Uma Analise de Literatura. Revista Brasileira de Ciências Sociais, v. 1, n. 3, p. 38-50, 1987.

LONGO, I. S. Ser adolescente e criança na sociedade brasileira: passado e presente da história dos direitos da juventude. In: III CONGRESSO INTERNACIONAL DE PEDAGOGIA SOCIAL, 3., 2010, São Paulo, Associação Brasileira de Educadores Sociais (ABES). Disponível em: <http:// www.proceedings.scielo.br/scielo.php?script=sci_isoref\&pid=MSC0000000092010000100013\&l $\mathrm{ng}=\mathrm{en}>$. Acesso em: 16 maio 2014.

LORENZI, Gisella W. Uma Breve História dos Direitos da Criança e do Adolescente no Brasil. 2007. Disponível em http://www.promenino.org.br. Acesso em 20/04/2015.

McADAM, D.; TARROW, S.; TILLY, C. Para mapear o confronto político. Lua Nova, São Paulo, n. 76, p. 11-48, 2009.

MISCHE, A. De estudantes a cidadãos: redes de jovens e participação política. Revista Brasileira de Educação, São Paulo, n. 5/6, p. 134-150, 1997.

MOVIMENTO PELOS DIREITOS DA CRIANÇA E DO ADOLESCENTE. Disponível em: <http://www.mdca.org.br/index.php>. Acesso em: 25 jul. 2013.

NASTARI, M. Políticas Públicas de atenção à infância e adolescência no Brasil: Uma breve abordagem sobre origens, diagnóstico e perspectivas. In: GARCÉS, M. et al. (Org.). Democracia y ciudadanía en el Mercosur. Santiago: LOM Ediciones, 2006.

PAOLI. M. C. Movimentos Sociais no Brasil: Em busca de um estatuto político. In: HELLMANN, M. Movimentos sociais e democracia no Brasil. "Sem a gente não tem jeito". São Paulo: Editora Marco Zero; ILDESFES - Instituto Latino-americano de Desenvolvimento Econômico e Social, 1995.

PALHETA. A. Sociedade Civil, Direitos Humanos e Adolescente em Conflito com a Lei $n^{\circ}$ 2.010. 263f. Dissertação (Mestrado Profissional Adolescente em Conflito com a Lei) Universidade Bandeirante Anhanguera, São Paulo: Unian, 2010. Disponível em: <http://www. uniban.br/pos/adolescente/pdfs/teses/2010/adriana.pdf>. Acesso em: 16 maio 2014.

PEREIRA, R. F. de S. Movimento de defesa dos direitos da criança e do adolescente: do alternativo ao alterativo. 1996. 155f. Dissertação (Mestrado em Serviço Social), Pontifícia Universidade Católica de São Paulo. São Paulo: PUC, 1996.

PINI, F. R. de O. Fóruns DCA: fios que tecem o movimento da infância e da adolescência na construção de caminhos para a democracia participativa. 2006. 190f. Dissertação (Doutorado em Serviço Social), Pontifícia Universidade Católica de São Paulo. São Paulo: PUC, 2006. 
PIRES. R. R. C. (Org.). Efetividade das instituiçóes participativas no Brasil: estratégias de avaliação. (Diálogos para o desenvolvimento, v. 7). Brasília: Ipea, 2011.

REDE EPCAT. Disponível em: <http://ecpatbrasil.org.br/?page_id=119>. Acesso em: 25 jul. 2013. SABATIER, P. A.; WEIBLE, C. M. The Advocacy Coalition Framework: innovations and clarifications. In: SABATIER, P. A. (Ed.) Theories of Policies Process. Boulder, CO: Westview Press, 2007, p. 189-222.

SCHERER-WARREN, I; LÜCHMANN, L. H. H. Movimentos sociais e participação institucional: introduzindo o debate. Política e Sociedade, Florianópolis, v. 10, n. 18, abr. 2011. Disponível em: <https://periodicos.ufsc.br/index.php/politica/article/viewFile/21757984.2011v10n18p9/17530>. Acesso em: 25 jul. 2013.

SANTOS, B. R. MNMMR: uma trajetória de luta e trabalho em defesa da criança e do adolescente no Brasil. São Paulo: MNMMR; UNICEF, 1994.

SILVA, M. K.; OLIVEIRA, G. de L. A face oculta(da) dos movimentos sociais: trânsito institucional e intersecção Estado-Movimento - uma análise do movimento de economia solidária no Rio Grande do Sul. Sociologias, Porto Alegre, ano 13, n. 28, p. 86-124, set./dez. 2011. Disponível em: <http://www.scielo.br/pdf/soc/v13n28/05.pdf>. Acesso em: 30 jul. 2013.

SKOCPOL, T. Being the state back in strategies of Analysis in Current Research. In: EVANS, P. E., RUESCHEMEYER, D.; SKOCPOL, T. (Ed.). Bringing the state back in. Cambridge: Cambridge University Press, 1997.

SOUZA, C. de. Para Munir Cury, transformação social vai além do Estatuto. [s. d.], [s. p.]. Promenino Fundaçáo Telefônica. Disponível em: <http://www.promenino.org.br/noticias/ arquivo/para-munir-cury-transformacao-social-vai-alem-do-estatuto>. Acesso em: 20 jul. 2013.

SWACKO, J. Participar vale a pena, mas...: a democracia participativa brasileira vista pelas lentes da utopia. In: SOUTO, A. L. S; PAZ, R. D. O da. (Org.). Novas Lentes sobre a Participaçáo: utopias, agendas e desafios. São Paulo: Instituto Pólis, 2012, p. 13-44. Disponível em: <http:// www.polis.org.br/uploads/1585/1585.pdf>. Acesso em: 28 jul. 2013.

TARROW, S. O poder em movimento. Movimentos sociais e confronto político. Petrópolis: Editora Vozes, 2009.

TATAGIBA, L. A questáo dos atores, seus repertórios de ação e implicaçóes para o processo participativo. In: Pires, R. R. C. (Org.). Efetividade das instituiçóes participativas no Brasil: estratégias de avaliação. (Diálogos para o desenvolvimento v.7). Brasília: IPEA, 2011. p. 171-186.

TILLY, C. Movimentos sociais como política. Revista Brasileira de Ciência Política, n. 3. p. 133160, Brasília, jan./jul. 2010. 
TRIBUNAL DE CONTAS DA UNIĀO. Disponível em: <http://portal2.tcu.gov.br.acesso>. Acesso em: 21 jul 2013.

Recebido em: 13.07.2014

Aprovado em: 01.03.2015

\section{The movement for the rights of children and adolescents and social control over the socio-educational policy: repertoires of socio-state interaction}

\section{Abstract}

This paper deals with the movement for the rights of children and adolescents (DCA movement) in its actions of incidence - or social control - on the socio-educational policy. It searches a new analytical perspective on this social movement that allows reflect on their results in the achievement of public policies for the realization of child and adolescents rights protection paradigm. To do this it was necessary to look for new theoretical frameworks appropriate to think this form of action, examining the repertoire of interaction between the movement and the state. Among them are the institutional participation through participatory institutions as Councils and Conferences, the occupation of positions in the state and especially the relationship between societal actors of DCA movement and state actors that are legally responsible to carry out public control over politics. The article is based on teacher research based on document analysis and field observation of actors and spaces of DCA social movement. Note the importance of articulating a movimentalistic theoretical perspective, focusing on the repertoires of collective action, with a policies analysis perspective. Analyze patterns of interdependence between social actors and the State is essential to escape the simplistic assessment that the interaction between state and movement leads to bureaucratization and cooptation and to understand the meaning and the place of movement in the social control of public policy.

Keywords: Social movement. Social control. Repertoires of socio-state interaction. Adolescents in conflict with the law. Socio-educational policy. 